
$\$$ Research Square
Preprints are preliminary reports that have not undergone peer review.
They should not be considered conclusive, used to inform clinical practice,
or referenced by the media as validated information.

\title{
Health-Promoting Factors Among Students in Higher Education within Health Care and Social Work: A Cross-Sectional Analysis of Baseline Data in a Multicentre Longitudinal Study
}

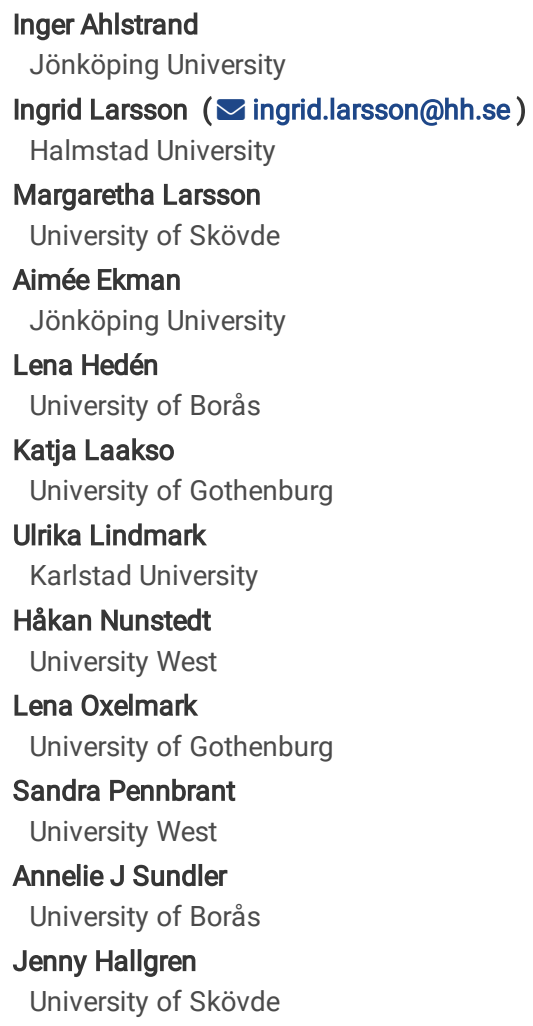

\section{Research Article}

Keywords: Health and health-promoting resources, Health behavior, Health-promoting lifestyle factors, Higher education, Occupational Balance Questionnaire, Salutogenesis, Salutogenic Health Indicator Scale, Sense of coherence, Students' health

Posted Date: October 21st, 2021

DOl: https://doi.org/10.21203/rs.3.rs-965295/v1

License: (c) (i) This work is licensed under a Creative Commons Attribution 4.0 International License. Read Full License 


\section{Abstract}

Background: Educational environments are considered important for strengthening students' health status and knowledge, which is associated with good educational outcomes. It has been suggested to establish healthy universities based on a salutogenic approach-namely, health promotion. The aim of this study was to describe health-promoting resources and factors among first-semester students in higher education in healthcare and social work.

Methods: This cross-sectional study is based on a survey provided to all students in seven healthcare and social work programmes from six universities in southern Sweden. The survey was performed in 2018 using a self-reported, web-based questionnaire focussing on general health and well-being, lifestyle factors and three validated instruments measuring health-promoting factors and processes-the Sense of Coherence (SOC) scale, Salutogenic Health Indicator Scale (SHIS) and Occupational Balance Questionnaire (OBQ).

Results: Of 2283 students, 851 completed the survey, where 742 (87.1\%) were women; 722 students participated in healthcare programmes, and 129 students participated in social work programmes. Most reported good general health and well-being ( $88.1 \%$ and $83.7 \%$, respectively). The total mean scores for the SOC scale, SHIS and OBQ were $59.09(S D=11.78), 44.04(S D=9.38)$ and $26.40(S D=7.07)$, respectively. Well-being and several health-promoting lifestyle factors were related to better general health and higher SOC, SHIS and OBQ scores. Multiple linear and logistic regressions showed that perceived well-being and no sleeping problems significantly predicted higher general health and higher SOC, SHIS and OBQ scores. Being less sedentary and non-smoking habits were significant predictors of higher SOC.

Conclusions: Swedish students in higher education within the healthcare and social work sector report good general health and well-being in the first semester, as well as health-promoting resources (i.e. SOC, SHIS and OBQ), and in some aspects, a healthy lifestyle. High-intensity exercise, no sleeping problems and non-smoking seem to be of importance to both general health and health-promotive resources. This study contributes to the health promotive characteristics of students in the healthcare and social work sectors, which is of importance for planning universities with a salutogenic approach.

\section{Background}

Health-promoting factors are of great importance during education and in preparing for future work and the professional role (1-3). A healthy work life is considered important, and health promotion for health service providers is needed to ensure a sustainable working life. Still, more knowledge is needed on the relationship between education and health and factors that may be important for future working-life balance among individuals $(4,5)$.

Household income (6) and several health and lifestyle factors, such as dietary patterns (7) and sleep disorders (8), have been found to influence students' health and academic progress performance. Students in higher education programmes suffer from different physical problems, such as neck, shoulder and/or back pain (9), as well as daytime sleepiness and sleep debt, which can put them at risk for mental health disorders, such as depression and anxiety (10, 11). Based on this, health-promoting strategies, such as physical activity, are recommended by the World Health Organization (12). Another positive association promoting health has been found between enrolment in health-related university courses and students' health promotion competencies $(13,14)$.

This study is grounded in the theoretical framework of salutogenesis (15), which is the theory behind health-promoting work aiming to promote health rather than targeting factors that cause disease (16). Essential to salutogenic theory is an understanding of health as a process that exists along a continuumnamely, the health/disease continuum. The most important concept in the theory is Sense of Coherence (SOC)-that is, comprehensibility, meaningfulness and manageability. These concepts represent a combination of people's ability to assess and understand the situation they are in and to find meaning, move in a health-promoting direction and manage the situation $(17,18)$. Research has shown a strong relationship between SOC and health and well-being (18). Influenced by salutogenic theory, health has also been described by Bringsén et al. (2009, p.4) as 'a positive subjective experience of oneself as a whole', which is why a holistic description of health, including an individuals' cognitive, physical and psychosomatic health, which is important to consider in health promotion research (19). Balance in life is an important health-promoting factor (20). Research has shown that occupational balance has an impact on health professionals (21) and could also be an important promotive factor for students within healthcare and social work fields.

Today, a need to focus on health promotion approaches has been stressed to strengthen positive aspects (18), not least for students in higher education programmes $(22,23)$. Integration of a health promotion approach in health education curricula has been successful $(24,25)$, and it is necessary to identify health-promoting factors among students during their education $(16,25)$. Therefore, improving students' health and health status are important for educational outcomes $(26,27)$. Still, more knowledge is needed to understand how a salutogenic approach can create good conditions for developing students' abilities and resources to feel well during their studies, making them better prepared for future sustainable working life. Knowledge of the working environment from a salutogenic perspective is not fully understood in education programmes in healthcare and social work, which is why there is a need for such studies. This is important knowledge that can form the basis for understanding the transition into and the establishment of the professional role. Therefore, this study presents baseline data from a longitudinal multicentre study focusing on health-promoting resources and factors for sustainable studies on higher education programmes and, by extension, a sustainable working life. The aim was to describe health, health-promoting resources and lifestyle factors reported by first-year students in higher education in health care and social work. In addition, we studied how health, health-promoting resources and lifestyle factors were associated.

\section{Methods And Design}

This is a cross-sectional study using baseline data from a multicentre longitudinal study involving Swedish students in higher education programmes in the healthcare and social work sectors (28). The Strengthening the Reporting of Observational Studies in Epidemiology (STROBE) guidelines have been followed to strengthen the trustworthiness of the study (29). 


\section{Setting and participants}

The study was conducted within the Swedish framework for 'Health Research in Collaboration', involving six universities in southern Sweden. The qualifications sought in the included higher educational programmes were those of biomedical laboratory scientist, diagnostic radiology nurse, occupational therapist, physiotherapist, registered dental hygienist, registered nurse and social worker. All students, who started their higher education in one of these programmes at the six universities in 2018 , were eligible and invited to participate in the study.

\section{Data collection}

Data were collected via a survey administered to all students in the selected programmes and universities in the spring and fall of 2018 . The survey was performed using a self-reported, web-based questionnaire (esMaker NX3 software), including questions regarding sociodemographic characteristics and questionnaires covering salutogenic factors, the individual's health, personal resources and health behaviour. The survey was sent out in the middle of the first semester, and three reminders were sent after that point (28).

\section{Measurements}

At baseline, a web-based questionnaire was used that included questions related to background-that is, the students' characteristics; it included questions about demographic characteristics; reason for choosing the education programme; general health and well-being; and health-promoting resources as measured by the SOC scale (15), the Salutogenic Health Indicator Scale (SHIS) (19) and the Occupational Balance Questionnaire (OBQ) (30). Questions related to health-promoting lifestyle factors were based on the Swedish Public Health survey (31).

\section{Background data}

Questions covering demographics were used to elicit information on participants' gender, age, ethnicity, family situation and residential area. Reasons for choosing the education programme (13 questions) were used to further describe the students' characteristics to understand their intentions and motivations to apply for a specific higher education programme and establish themselves in the profession.

\section{Health and health-promoting resources}

General health and perceived well-being were measured as one overall single question and dichotomised as excellent/very good/good (1) or fairly good/bad (0).

The Sense of Coherence (SOC) was measured using the 13-item SOC scale (15), examining the individual's health-promoting resources. The SOC scale's items relate to comprehensibility (five items), manageability (four items) and meaningfulness (four items), an a 7-point semantic scale is used for responding to each item. The total score ranges from 13 to 91, and a high score indicates a strong SOC. The scale has been translated into Swedish (32). It has good psychometric properties and high validity and reliability, and it has been found to be a good indicator of health (33).

The SHIS comprises 12 items (19) and is associated with salutogenic and holistic descriptions of health, including cognitive, physical and psychosomatic health. This scale examines intrapersonal characteristics and interactive functions on a 6-point scale, ranging from negative (scored at 1) to positive (scored at 6). The total score ranges from 12 to 72 , and a high score indicates better health. The SHIS's validity has been shown to be high (19).

The $O B Q(30)$ measures occupational balance and focusses on satisfaction with the amount and variation of occupations. It comprises 11 items with a 4 point ordinal scale ranging from 'completely disagree' (scored at 0 ) to 'completely agree' (scored at 3). High scores mean high levels of experienced occupational balance. The OBQ was developed in Sweden and has good content validity, good internal consistency and sufficient test-retest reliability (20, 30).

\section{Health-promoting lifestyle factors}

Eight questions from the Swedish Public Health survey assessed health-promoting lifestyle factors (31). These including high-intensity exercise (dichotomised as yes > 60-90 minutes/week (1), no < 30-60 minutes/week (0)), moderate-intensity physical activity (dichotomised as yes > 150 minutes/week (1), no < 150 minutes/week (0)), sedentary (more than 10 hours (1), no (0)), sleeping problems (yes (1), no (0)), daily intake of vegetables (yes (1), less frequency than daily intake (0)), consumption of alcohol (yes (1), < once per month/no (0)), smoking (yes (1), seldom/no (0)) and daily snuff (yes (1), seldom/no (0)).

\section{Outcome variables}

The outcome variables in this study were general health, SOC, SHIS and OBQ.

\section{Data analysis}

Descriptive analysis was used to describe the background characteristics and reasons for choosing the selected programme. The $\chi^{2}$ test, $t$-test, MannWhitney $\mathrm{U}$ and Kruskal-Wallis test were used for describing health-promoting resources and differences in general health, health-promoting lifestyle factors (perceived well-being, physical exercise, everyday physical activities, being sedentary more than 10 hours per day, sleeping problems, intake of vegetables, consumption of alcohol, smoking, daily snuff intake) in terms of general health, SOC, SHIS and OBQ scores, respectively. Factors that were significantly associated with general health, SOC, SHIS and OBQ from the $\chi^{2}$ test, $t$-test and Mann-Whitney $\mathrm{U}$, were included in a multiple logistic regression and a multiple linear regression analysis. A $p$-value $<0.05$ was considered significant. All data were analysed using SPSS Statistics 27 .

\section{Results}




\section{Student characteristics}

A total of 2283 students were invited to participate in the study, and $851(37 \%)$ of them completed the baseline survey. The participants were all students in programmes in healthcare and social work sectors for qualification as one of the following professions: biomedical laboratory scientists $(n=51)$, diagnostic radiology nurses $(n=26)$, occupational therapists $(n=58)$, physiotherapists $(n=24)$, registered dental hygienists $(n=27)$, registered nurses $(n=536)$ and social workers $(n=129)$.

Among the 851 included students in higher education programmes in the healthcare and social work sectors, 742 (87.1\%) were women and 106 men (12.9\%). The respondents had a mean age of 28 years. A total of $16.2 \%$ of the students were foreign-born, and $30.0 \%$ reported that one or both of their parents were foreign-born. Living in a rural area was reported by $12.7 \%$ of respondents, and $17.4 \%$ of the students were living alone (Table 1 ).

\section{Reason for choosing the programme}

The most common reasons $(87.0 \%-92.8 \%)$ for choosing the selected programme and career were employment security, working with people, helping people, a broad education, possibilities for different career paths, varying tasks, intellectually stimulating, getting a permanent job and use of knowledge from the student's education. Teamwork and closeness to a university were the least common reasons $(61.8 \%-64.0 \%)$. There were some differences between the reasons for choosing the programme (Table 2).

\section{Health and health-promoting resources}

Overall, the students reported good general health (88.1\%) and good general well-being (83.7\%). The mean total SOC score was $59.09(S D=11.78)$, and the means for the subscales were as follows: Comprehensibility, $20.69(S D=5.39)$; Meaningfulness, $20.62(S D=4.10)$; and Manageability, 17.82 ( $S D=4.37)$. The total mean SHIS score was $44.04(S D=9.38)$. There were significant differences between women and men in all health-promoting resources reported, besides concerning $\mathrm{OBQ}$ and the total SOC score. Categorised into the three SOC dimensions, men had statistically significantly higher Comprehensibility and Manageability scores than women did, but women reported higher Meaningfulness scores. There were no statistically significant differences between students in different educational programmes for the OBQ or the total SOC score. However, there were significant differences for the SHIS, where occupational therapy students had a statistically significantly higher SHIS score $(60.8 ; S D=11.0)$ compared with all other student groups. Table 3 shows more details and health-promoting resources for each educational programme.

\section{Health-promoting lifestyle factors}

In the total group, $85.3 \%$ of respondents were non-smokers and $86.7 \%$ were not daily snuffers; $57.6 \%$ reported low alcohol consumption (never or once a month) consumption and $60, .0 \%$ had a daily intake of vegetables. High-intensity exercise for more than 60 minutes/week and moderate-intensity physical activity for more than 150 minutes/week were performed by $47.5 \%$ and $32.7 \%$ of respondents, respectively, whereas $25.8 \%$ were sedentary for more than 10 hours per day. Moreover, $59.7 \%$ reported no sleeping problems. The students' health-promoting lifestyle factors in total and in each educational programme are presented in Table 1.

\section{Associations between health-promoting resources and lifestyle factors}

The participants reporting better general health had better perceived well-being, performing high-intensity exercise, being less sedentary, having no sleeping problems, consuming vegetables daily, low or no consumption of alcohol and no smoking. Significantly higher SOC, SHIS and OBQ were seen among participants who had better general health, perceived well-being, no sleeping problems and low or no consumption of alcohol. Being less sedentary and having a daily intake of vegetables were associated with higher SOC and SHIS. Regarding exercise and physical activity, high-intensity exercise was associated with higher SHIS and OBQ, whereas moderate-intensity physical activity was associated with higher SOC. However, the use of daily snuff was not significantly associated with general health or higher SOC, SHIS or OBQ (Table 4).

When entering significantly associated factors based on the univariate analyses in multiple linear regressions, perceived well-being and no sleeping problems were significant predictors of better general health and higher SOC, SHIS and OBQ scores. In addition, performing high-intensity exercise predicted better general health; in turn, better general health predicted higher SHIS scores. Being less sedentary and non-smoking habits were significant predictors of higher SOC (Tables 5-8).

\section{Discussion}

This study describes the associations between general health, perceived well-being, health-promoting resources measured by the SOC, SHIS and OBQ scores and health-promoting lifestyle factors, comparing results from students in several higher education programmes. The main results showed that of the firstyear students in higher education within health care and social work, most seemed to report good general health and well-being, as well as having healthpromoting resources and a health-promoting lifestyle. Better general health was also associated with better perceived well-being, high-intensity exercise, no sleeping problems and not smoking. Associations related to health-promoting resources showed that healthy values in terms of the SOC, SHIS and OBQ scores were associated with better perceived well-being. Students having higher SOC was related to moderate-intensity physical activity (everyday physical 
activities) and better $\mathrm{OBQ}$ was related to high-intensity exercise. All three health resources were related to a lack of sleeping problems. These results support the importance of maintaining sustainable health-promoting strategies during higher education, as has been described in earlier research (22-25).

\section{Health and health-promoting resources}

In the results, most students reported good general health and good general well-being. This is consistent with previous research among nursing students (34); however, previous studies have also found that general health and well-being decline during the 3-year education (35).

In this study, health-promoting resources were measured by the SOC, SHIS and OBQ scores. In earlier studies, the SOC has been found to be strongly related to health $(36,37)$, and the SHIS and OBQ have been suggested to be reliable salutogenic health measurement instruments $(19,30)$. The mean SOC score was 59.09 in the current study, which is somewhat lower compared with that reported in an earlier study based on a general Swedish population aged 20 and 30 years old (63.3 and 70.0, respectively) (38). The differences may be related to the different contexts-that is, aspects related to the student situation and health. A health-promoting strategy could involve finding interventions to strengthen the salutogenic dimensions included in these three resources. For example, the three dimensions of the SOC have been used as a base for interventions among students in transcultural learning environments (39).

\section{Health-promoting lifestyle factors}

Previous research has stated that higher education students' health-related lifestyle is a cause for concern and suggests that universities need to focus on health-promotion work among students $(24,40)$. In the current study, one-third of the participants met the recommendations of physical activity of at least 150 minutes of moderate-intensity physical activity per week, and nearly half of the participants were exercising for at least $60-90$ minutes of high-intensity exercise per week. This is in line with the general population in Sweden (41). However, it is lower than previous research among nursing students, in which three-quarters met the recommendations for physical activity in their first year of higher education (34)-although this rate declined during the 3-year education (35). Based on research from other industrial countries, around two-thirds met the recommendations for physical activity of 150 minutes of moderate activity per week, in Australia and Spain $(42,43)$, whereas only one-third did so in England, Greece and the United States (40, 44, 45). In our study, gender was not associated with level of physical activity, but other research has shown that gender is associated with physical activity, with women having almost twice the risk of insufficient physical activity compared with men $(40,45)$.

Most students had no sleeping problems; however, there were variations between the programmes. Nevertheless, 4 out of 10 students reported sleep problems. This is in contrast to previous research among nursing students, where only 1 in 10 students reported sleep problems during the first year of higher education (34)-although sleep problems did increase during the third year (35). Sleep could have an impact on anxiety and depression (10, 11), and it is essential to serve several important physical functions, such as recuperation from infectious diseases and consolidation of memories (46). A recent literature review and meta-analysis showed that sleep disruption is high among medical students, and this severely impairs learning ability and affects academic performance (47). Thus, studies aiming to follow up sleep habits during education, as well as interventions to improve sleep quality for students within healthcare and social work, are recommended.

The results show that the daily intake of vegetables among the students is in line with studies among students in the United States (45). Of all students, most were non-smokers and non-daily snuffers; over half the students reported low alcohol consumption. The prevalence of smoking and alcohol consumption among the participating students is in line with research from other countries in Europe $(35,40,43)$.

\section{Associations between general health, health-promoting resources and lifestyle factors}

This study shows an association between self-reported good general health and higher SOC, SHIS and OBQ scores. Self-reported good general health and high SHIS and OBQ scores were associated with better perceived well-being, performing high-intensity exercise and being less sedentary. Being less sedentary and performing moderate-intensity physical activities were also associated with higher SOC scores. This is confirmed by previous research revealing associations between perceived health and the degree of physical activity. Being intensively physically active entails a better perceived health-related quality of life (48).

The current study also shows that having no sleeping problems was significantly associated with self-reported general better health and higher SOC, SHIS and OBQ scores. A national survey in Norway including all higher education students showed that the mean sleep duration on weekdays was just under 7.5 hours per night and did not meet the students' self-reported sleep needs or sleep recommendations; in contrast, on weekends, the mean sleep duration was almost 8.5 hours per night. In the last decade, the proportion of higher education students reporting sleep problems has increased, rising from $23 \%$ in 2010 to $31 \%$ in 2018; moreover, $22 \%$ of men and $34 \%$ of women meet the criteria for insomnia (49). Sleep problems are associated with poorer academic skills and results among students in higher education (50-52). Since sleep problems are both prevalent and increasing (49) and influence academic results (50, 51, 53), sleep interventions can be important in health promotion work to improve health outcomes and overall academic performance among students (53).

This study shows associations between a daily intake of vegetables and self-reported good general health, combined with higher SOC and SHIS scores. In line with this, higher SOC scores have shown a strong association with healthy dietary patterns (54). Based on previous research, it appears to be common among students in higher education to have an unbalanced diet; for example, they may skip breakfast regularly or not reach the general vegetable intake recommendations $(40,42,44)$; moreover, they may experience unfavourable and differential changes to their dietary intakes and diet quality during the transition to higher education life (55). Higher education students' health behaviours seem to be risk factors that need attention, and Yahia, Wang (45) argue that students in the United States, especially male students, might benefit from nutrition education programmes that focus on translating theoretical nutritional knowledge into daily-life applications, whereas female students would benefit from reducing the time spent in sedentary activities and being more physically active (45).

Higher education and universities are an important part of student life. Therefore, higher education institutions must increase their accountability and willingness to design health-promotion interventions in the education and learning environment, focussing on multiple lifestyle issues (43). Moreover, they

Page 5/14 
should include health promotion in their core values (40) with the intention of preparing the students for future sustainable working life.

\section{Strengths and limitations}

Aiming to improve the research standard and reduce publication bias, the study protocol for this study was previously peer reviewed and published (28), which must be considered as a strength. This study is also the first step in a data collection series that is, a baseline aiming to follow up students on higher education programmes in the healthcare and social work sectors and the post-graduation period as new professionals. Thus, this study provides an important overview of health, health-promoting resources and lifestyle factors reported by first-year students in higher education within this sector. As far as we know, research targeting the healthcare and social work sector to predict possible salutogenic factors instead of pathogenic factors is limited. A strength is that validated instruments developed to catch health-promoting factors have been used. However, some limitations must be considered. Power calculation is often a recommendation for calculating statistical analyses and for appropriate generalisation to the population (56). This study was considered a total population study representing all students at six university programmes within health care and social work. Thus, the results can only be generalised to this population.

\section{Conclusions}

Most first-year Swedish students from six universities in higher education within healthcare and social work programmes seem to report good health, as well as important health-promoting resources-that is, they have high SOC, SHIS and OBQ scores-and a healthy lifestyle in some respects. High-intensity exercise, no sleeping problems and non-smoking are positively associated with general health and health-promotive resources. Universities are important arenas for health promotion as partners in multisectoral health improvements. This study contributes to delineating the characteristics of students in the healthcare and social work sectors.

\section{Abbreviations}

OBQ: Occupational Balance Questionnaire; SHIS: Salutogenic Health Indicator Scale; SOC: Sense of coherence.

\section{Declarations}

\section{Ethics approval and consent to participate}

The study followed the recommendations in the Declaration of Helsinki (World Medical Association, 2013). Ethical approval was obtained from the Linköping Regional Research Ethics Committee (Dnr 2017/211-31). Personal data were processed in accordance with the EU General Data Protection Regulation (GDPR2016/679). All participants were informed of the purpose of the study; that participation was voluntary; that they could leave the study at any time; and that all data would be handled confidentially. Written informed consent was obtained from all participants in such a way that the information letter attached to the questionnaire stated that by submitting the completed questionnaire, consent to participate in the study was given.

\section{Consent for publication}

Not applicable.

\section{Availability of data and materials}

The datasets and materials used and/or analysed during the current study are available from the corresponding author upon reasonable request.

\section{Competing interests}

The authors declare that they have no competing interests.

\section{Funding}

The six universities in the Swedish framework for 'Health Research in Collaboration' and Region Västra Götaland are jointly financing the cost of project management. All authors receive regular research support from their respective universities. This research project has not received external funding and has not undergone peer review by the funding body.

\section{Authors' Contributions}

All authors made significant contributions to the study design by collaboratively identifying the research questions. IA and UL were responsible for the data collection. The data analysis was done by IA and JH and interpreted by IA, JH, IL and ML. The manuscript was drafted by IA, IL, ML and JH, while all authors provided critical revision of the paper in terms of important intellectual content. All authors have read and approved the final submitted version.

\section{Acknowledgements}

For their support and encouragement of the study, we would like to thank research coordinator Irène Carlensberg (the University of Gothenburg) and the board of the Swedish framework for 'Health Research in Collaboration'.

\section{References}


1. Nunstedt $H$, Eriksson M, Obeid A, Hillstrom L, Truong A, Pennbrant S. Salutary factors and hospital work environments: a qualitative descriptive study of nurses in Sweden. BMC Nurs. 2020;19(1):125.

2. Por J, Barriball L, Fitzpatrick J, Roberts J. Emotional intelligence: its relationship to stress, coping, well-being and professional performance in nursing students. Nurse education today. 2011;31(8):855-60.

3. Ruiz-Aranda D, Extremera N, Pineda-Galan C. Emotional intelligence, life satisfaction and subjective happiness in female student health professionals: the mediating effect of perceived stress. Journal of psychiatric and mental health nursing. 2014;21(2):106-13.

4. European_Association_for_Quality_Assurance_in_Higher_Education. Standards and guidelines for quality assurance in the European Higher Education Area (ESG). ENQA Brussels; 2015.

5. Statens_Folkhälsoinstitut. Hälsa i arbetslivet. Kunskapsunderlag för Folkhälsopolitisk rapport 2010. Östersund: Strömberg: Statens Folkhälsoinstitut; 2011.

6. Veenstra G, Vanzella-Yang A. Does household income mediate the association between education and health in Canada? Scandinavian journal of public health. 2020:1403494820917534.

7. Williams SL, Vandelanotte C, Irwin C, Bellissimo N, Heidke P, Saluja S, et al. Association between dietary patterns and sociodemographics: A crosssectional study of Australian nursing students. Nursing \& health sciences. 2020;22(1):38-48.

8. Gianfredi V, Nucci D, Tonzani A, Amodeo R, Benvenuti AL, Villarini M, et al. Sleep disorder, Mediterranean Diet and learning performance among nursing students: inSOMNIA, a cross-sectional study. Ann Ig. 2018;30(6):470-81.

9. Lovgren M, Gustavsson P, Melin B, Rudman A. Neck/shoulder and back pain in new graduate nurses: A growth mixture modeling analysis. International journal of nursing studies. 2014;51(4):625-39.

10. Dickinson DL, Wolkow AP, Rajaratnam SMW, Drummond SPA. Personal sleep debt and daytime sleepiness mediate the relationship between sleep and mental health outcomes in young adults. Depress Anxiety. 2018;35(8):775-83.

11. Hasson D, Gustavsson P. Declining sleep quality among nurses: a population-based four-year longitudinal study on the transition from nursing education to working life. PloS one. 2010;5(12):e14265.

12. World_Health_Organization. Global recommendations on physical activity for health Geneva: World Health Organization; 2010.

13. Sukys S, Cesnaitiene VJ, Ossowsky ZM. Is Health Education at University Associated with Students' Health Literacy? Evidence from Cross-Sectional Study Applying HLS-EU-Q. BioMed Research International. 2017;2017:8516843.

14. Balmer D, King A, Moloney W, Moselen E, Dixon R. Nursing students and health literacy: The effect of region and programme level. Nurse Education in Practice. 2020;42:102688.

15. Antonovsky A. Unraveling the mystery of health: How people manage stress and stay well: Jossey-bass; 1987.

16. Mittelmark M, Bull T. The salutogenic model of health in health promotion research. Glob Health Promot. 2013;20(2):30-8.

17. Eriksson M. The Sense of Coherence in the Salutogenic Model of Health. In: Mittelmark M, Sagy S, Eriksson M, Bauer G, Pelikan J, Lindström B, et al., editors. The Handbook of Salutogenesis. New York: Springer; 2017. p. 91-6.

18. Mittelmark M, Sagy S, Eriksson M, Bauer G, Pelikan J, Lindström B, et al. The handbook of salutogenesis New York: Springer; 2017.

19. Bringsen A, Andersson HI, Ejlertsson G. Development and quality analysis of the Salutogenic Health Indicator Scale (SHIS). Scandinavian journal of public health. 2009;37(1):13-9.

20. Wagman P, Hakansson C. Exploring occupational balance in adults in Sweden. Scand J Occup Ther. 2014;21(6):415-20.

21. Wagman P, Lindmark U, Rolander B, Wahlin C, Hakansson C. Occupational balance in health professionals in Sweden. Scand J Occup Ther. 2017;24(1):18-23.

22. Blake H, Harrison C. Health behaviours and attitudes towards being role models. Br J Nurs. 2013;22(2):86-94.

23. Malik S, Blake H, Batt M. How healthy are our nurses? New and registered nurses compared. Br J Nurs. 2011;20(8):489-96.

24. Dooris M, Doherty S. Healthy universities-time for action: a qualitative research study exploring the potential for a national programme. Health Promot Int. 2010;25(1):94-106.

25. McCuaig L, Quennerstedt M, Macdonald D. A salutogenic, strengths-based approach as a theory to guide HPE curriculum change. Asia-Pacific Journal of Health, Sport and Physical Education. 2013;4(2):109-25.

26. Barnekow V, Buijs G, Clift S, Bruun Jensen B, Paulus P, Rivett D, et al. Health-promoting schools: a resource for developing indicators. WHO Regional Office for Europe, the European Commission and the Council of Europe: International Planning Committee of European Network of Health Promoting Schools; 2006.

27. Whitehead D. Before the cradle and beyond the grave: a lifespan/settings-based framework for health promotion. Journal of clinical nursing. 2011;20(1516):2183-94.

28. Lindmark U, Ahlstrand I, Ekman A, Berg L, Heden L, Kallstrand J, et al. Health-promoting factors in higher education for a sustainable working life protocol for a multicenter longitudinal study. BMC public health. 2020;20(1):233.

29. Vandenbroucke JP, von Elm E, Altman DG, Gotzsche PC, Mulrow CD, Pocock SJ, et al. Strengthening the Reporting of Observational Studies in Epidemiology (STROBE): explanation and elaboration. Epidemiology. 2007;18(6):805-35.

30. Wagman P, Hakansson C. Introducing the Occupational Balance Questionnaire (OBQ). Scand J Occup Ther. 2014;21(3):227-31.

31. The_Public_Health_Agency_of_Sweden. Public Health reporting. The national public health survey. Stockholm: The public Health Agency of Sweden; 2018 . 
32. Langius A, Bjorvell H. Coping ability and functional status in a Swedish population sample. Scand J Caring Sci. 1993;7(1):3-10.

33. Eriksson M, Lindstrom B. Validity of Antonovsky's sense of coherence scale: a systematic review. J Epidemiol Community Health. 2005;59(6):460-6.

34. Evans JM, Eades CE, Cameron DM. Health and health behaviours among a cohort of first year nursing students in Scotland: A self-report survey. Nurse Educ Pract. 2019;36:71-5.

35. Evans JM, Andreis F, Cameron DM, Eades CE. How does the self-reported health of undergraduate nursing students change during their degree programme? Survey results from a Scottish University. BMC Nurs. 2021;20(1):44.

36. Eriksson M, Kerekes N, Brink P, Pennbrant S, Nunstedt $\mathrm{H}$. The level of sense of coherence among Swedish nursing staff. Journal of advanced nursing. 2019;75(11):2766-72.

37. Eriksson M, Lindstrom B. Antonovsky's sense of coherence scale and the relation with health: a systematic review. J Epidemiol Community Health. 2006;60(5):376-81.

38. Lindmark U, Stenstrom U, Gerdin EW, Hugoson A. The distribution of "sense of coherence" among Swedish adults: a quantitative cross-sectional population study. Scandinavian journal of public health. 2010;38(1):1-8.

39. Mayer $\mathrm{CH}$, Boness $\mathrm{C}$. Interventions to promoting sense of coherence and transcultural competences in educational contexts. Int Rev Psychiatry. 2011;23(6):516-24.

40. Aceijas C, WaldhausI S, Lambert N, Cassar S, Bello-Corassa R. Determinants of health-related lifestyles among university students. Perspect Public Health. 2017;137(4):227-36.

41. Loyen A, Clarke-Cornwell AM, Anderssen SA, Hagstromer M, Sardinha LB, Sundquist K, et al. Sedentary Time and Physical Activity Surveillance Through Accelerometer Pooling in Four European Countries. Sports medicine. 2017;47(7):1421-35.

42. Whatnall MC, Patterson AJ, Brookman S, Convery P, Swan C, Pease S, et al. Lifestyle behaviors and related health risk factors in a sample of Australian university students. J Am Coll Health. 2020;68(7):734-41.

43. Bennasar-Veny M, Yanez AM, Pericas J, Ballester L, Fernandez-Dominguez JC, Tauler P, et al. Cluster Analysis of Health-Related Lifestyles in University Students. Int J Environ Res Public Health. 2020;17(5).

44. Kritsotakis G, Georgiou ED, Karakonstandakis G, Kaparounakis N, Pitsouni V, Sarafis P. A longitudinal study of multiple lifestyle health risk behaviours among nursing students and non-nursing peers. Int J Nurs Pract. 2020;26(6):e12852.

45. Yahia N, Wang D, Rapley M, Dey R. Assessment of weight status, dietary habits and beliefs, physical activity, and nutritional knowledge among university students. Perspectives in Public Health. 2015;136(4):231-44.

46. Krueger JM, Frank MG, Wisor JP, Roy S. Sleep function: Toward elucidating an enigma. Sleep Med Rev. 2016;28:46-54.

47. Seoane HA, Moschetto L, Orliacq F, Orliacq J, Serrano E, Cazenave MI, et al. Sleep disruption in medicine students and its relationship with impaired academic performance: A systematic review and meta-analysis. Sleep Med Rev. 2020;53:101333.

48. de-Mateo-Silleras B, Camina-Martin MA, Cartujo-Redondo A, Carreno-Enciso L, de-la-Cruz-Marcos S, Redondo-Del-Rio P. Health Perception According to the Lifestyle of University Students. J Community Health. 2019;44(1):74-80.

49. Sivertsen B, Vedaa O, Harvey AG, Glozier N, Pallesen S, Aaro LE, et al. Sleep patterns and insomnia in young adults: A national survey of Norwegian university students. J Sleep Res. 2019;28(2):e12790.

50. Hayley AC, Sivertsen B, Hysing M, Vedaa O, Overland S. Sleep difficulties and academic performance in Norwegian higher education students. Br J Educ Psychol. 2017;87(4):722-37.

51. Vedaa $\varnothing$, Erevik EK, Hysing M, Hayley AC, Sivertsen B. Insomnia, sleep duration and academic performance: a national survey of Norwegian college and university students. Sleep Medicine: X. 2019;1:100005.

52. Gilbert SP, Weaver CC. Sleep quality and academic performance in university students: A wake-up call for college psychologists. Journal of college student psychotherapy. 2010;24(4):295-306.

53. Marta OFD, Kuo SY, Bloomfield J, Lee HC, Ruhyanudin F, Poynor MY, et al. Gender differences in the relationships between sleep disturbances and academic performance among nursing students: A cross-sectional study. Nurse education today. 2020;85:104270.

54. Lindmark U, Stegmayr B, Nilsson B, Lindahl B, Johansson I. Food selection associated with sense of coherence in adults. Nutrition journal. $2005 ; 4: 9$.

55. Beaudry KM, Ludwa IA, Thomas AM, Ward WE, Falk B, Josse AR. First-year university is associated with greater body weight, body composition and adverse dietary changes in males than females. PloS one. 2019;14(7):e0218554.

56. Price JH, Daek JA, Murnan J, Dimmig J, Akpanudo S. Power analysis in survey research: Importance and use for health educators. American Journal of Health Education. 2005;36(4):202-9.

\section{Tables}

Tabel 1. Participants' characteristics and health-promoting lifestyle factors, totally, in gender and educational program 


\begin{tabular}{|c|c|c|c|c|c|c|c|c|c|c|c|}
\hline & Totally & Women & Men & $\begin{array}{l}\text { Biomedical } \\
\text { laboratory } \\
\text { scientist, } \\
\text { (Clin Phys) } \\
\mathrm{n}=18\end{array}$ & $\begin{array}{l}\text { Biomedical } \\
\text { laboratory } \\
\text { scientist, } \\
\text { (Lab } \\
\text { Med) }\end{array}$ & $\begin{array}{l}\begin{array}{l}\text { Diagnostic } \\
\text { radiology } \\
\text { nurses }\end{array} \\
\mathrm{n}=26\end{array}$ & $\begin{array}{l}\text { Occupational } \\
\text { therapist }\end{array}$ & $\begin{array}{l}\text { Physio- } \\
\text { therapist }\end{array}$ & $\begin{array}{l}\text { Registered } \\
\text { dental } \\
\text { hygienists } \\
\mathrm{n}=27\end{array}$ & $\begin{array}{l}\text { Registered } \\
\text { nurse }\end{array}$ & $\begin{array}{l}\text { Soci } \\
\text { work }\end{array}$ \\
\hline & $N=851$ & $n=742$ & $n=106$ & & $n=33$ & & $\pi=58$ & $n=24$ & & $n=536$ & $n=1:$ \\
\hline $\begin{array}{l}\text { Age, years, Md } \\
\text { (IQR) }\end{array}$ & $26(8)$ & $26(7)$ & $28(8)$ & $23.5(8)$ & $25(5)$ & $25.5(11)$ & $27(8)$ & $26(5.75)$ & $26(8)$ & $26.5(9)$ & 25( \\
\hline $\begin{array}{l}\text { Gender, women, } \\
\text { n (\%) }\end{array}$ & $\begin{array}{l}742 \\
(87.1)\end{array}$ & & & 16 (88.9) & $29(87.9)$ & $23(88.5)$ & $49(84.5)$ & $17(70.8)$ & $24(88.9)$ & $473(88.2)$ & $\begin{array}{l}110 \\
(85 .:\end{array}$ \\
\hline $\begin{array}{l}\text { Born in Sweden } \\
\text { (Yes) } n(\%)\end{array}$ & $\begin{array}{l}714 \\
(83.8)\end{array}$ & $\begin{array}{l}624 \\
(84.1)\end{array}$ & $\begin{array}{l}87 \\
(82.1)\end{array}$ & $13(72.2)$ & $28(84.8)$ & $22(84.6)$ & 49 (84.5) & $22(91.7)$ & $18(66.7)$ & 445 (83.0) & $\begin{array}{l}116 \\
(89 .\end{array}$ \\
\hline $\begin{array}{l}\text { Both parents } \\
\text { born in Sweden } \\
\mathrm{n}(\%)\end{array}$ & $\begin{array}{l}596 \\
(70.0)\end{array}$ & $\begin{array}{l}526 \\
(70.9)\end{array}$ & $\begin{array}{l}67 \\
(63.2)\end{array}$ & $8(44.4)$ & $22(66.7)$ & $15(57.7)$ & $38(65.5)$ & $22(91.7)$ & $9(33.3)$ & 376 (70.1) & $\begin{array}{l}105 \\
(81 .\end{array}$ \\
\hline $\begin{array}{l}\text { One parent } \\
\text { born in Sweden } \\
\mathrm{n}(\%)\end{array}$ & $\begin{array}{l}88 \\
(10.3)\end{array}$ & $\begin{array}{l}74 \\
(10.0)\end{array}$ & $\begin{array}{l}14 \\
(13.2)\end{array}$ & $2(11.1)$ & $4(12.1)$ & $3(11.5)$ & $8(13.8)$ & $1(4.2)$ & $2(7.4)$ & $57(10.6)$ & $\begin{array}{l}11 \\
(8.5,\end{array}$ \\
\hline $\begin{array}{l}\text { Both parents } \\
\text { born in another } \\
\text { country } \mathrm{n}(\%)\end{array}$ & $\begin{array}{l}168 \\
(19.7)\end{array}$ & $\begin{array}{l}145 \\
(19.5)\end{array}$ & $\begin{array}{l}23 \\
(21.7)\end{array}$ & $7(38.9)$ & $7(21.2)$ & $6(23.1)$ & $10(17.2)$ & $1(4.2)$ & $14(51.9)$ & $108(20.1)$ & $\begin{array}{l}47 \\
(36 .\end{array}$ \\
\hline $\begin{array}{l}\text { Residential } \\
\text { area (rural) n } \\
\text { (\%) }\end{array}$ & $\begin{array}{l}109 \\
(12.7)\end{array}$ & $\begin{array}{l}100 \\
(13.5)\end{array}$ & $8(7.5)$ & $2(11.1)$ & $2(6.1)$ & $2(7.7)$ & $5(8.6)$ & $1(4.2)$ & $4(14.8)$ & 76 (14.2) & $\begin{array}{l}15 \\
(11.1\end{array}$ \\
\hline
\end{tabular}

Who do you

share a home

with?

\begin{tabular}{|c|c|c|c|c|c|c|c|c|c|c|c|}
\hline Living alone & $\begin{array}{l}148 \\
(17.4)\end{array}$ & $\begin{array}{l}123 \\
(16.6)\end{array}$ & $\begin{array}{l}25 \\
(23.6)\end{array}$ & $5(27.8)$ & $3(9.1)$ & $7(26.2)$ & $10(17.2)$ & $7(29.2)$ & $7(25.9)$ & $84(15.7)$ & $\begin{array}{l}25 \\
(19 .\end{array}$ \\
\hline $\begin{array}{l}\text { Parents } \\
\text { /siblings }\end{array}$ & $\begin{array}{l}202 \\
(23.7)\end{array}$ & $\begin{array}{l}174 \\
(23.5)\end{array}$ & $\begin{array}{l}26 \\
(24.5)\end{array}$ & $6(33.3)$ & $10(30.3)$ & $6(23.1)$ & $15(25.9)$ & $7(29.2)$ & $7(25.9)$ & $125(23.3)$ & $\begin{array}{l}26 \\
(20 .\end{array}$ \\
\hline $\begin{array}{l}\text { Husband/wife/ } \\
\text { partner }\end{array}$ & $\begin{array}{l}355 \\
(41.7)\end{array}$ & $\begin{array}{l}317 \\
(42.7)\end{array}$ & $\begin{array}{l}36 \\
(34.0)\end{array}$ & 3 (16.7) & 13 (39.4) & $9(34.6)$ & $21(36.2)$ & 8 (33.3) & $8(29.6)$ & $236(44.0)$ & $\begin{array}{l}56 \\
(43 .\end{array}$ \\
\hline Other adults & $\begin{array}{l}73 \\
(8.6)\end{array}$ & $\begin{array}{l}60 \\
(8.1)\end{array}$ & $\begin{array}{l}13 \\
(12.3)\end{array}$ & 2(11.1) & 5 (15.2) & $1(3.8)$ & 8 (13.8) & $3(12.5)$ & $1(3.7)$ & $37(6.9)$ & $\begin{array}{l}16 \\
(12 .\end{array}$ \\
\hline Children & $\begin{array}{l}97 \\
(11.4)\end{array}$ & $\begin{array}{l}89 \\
(12.0)\end{array}$ & $8(7.5)$ & $2(11.1)$ & $3(9.1)$ & 3 (11.5) & $5(8.6)$ & 0 & $4(14.8)$ & 71 (13.2) & $9(7$. \\
\hline
\end{tabular}

Health-

promoting

lifestyle factors

\begin{tabular}{|c|c|c|c|c|c|c|c|c|c|c|}
\hline $\begin{array}{l}\text { General health } \\
(\text { Good) } \mathrm{n}(\%)\end{array}$ & $\begin{array}{l}751 \\
(88.1)\end{array}$ & $\begin{array}{l}660 \\
(88.9)\end{array}$ & $\begin{array}{l}90 \\
(84.9)\end{array}$ & $17(94.4)$ & $29(87.9)$ & $21(80.8)$ & $54(93.1)$ & $23(95.8)$ & $24(88.9))$ & 472 (88.1) \\
\hline $\begin{array}{l}\text { Perceived } \\
\text { wellbeing } \\
\text { (Good) n (\%) }\end{array}$ & $\begin{array}{l}713 \\
(83.7)\end{array}$ & $\begin{array}{l}620 \\
(83.6)\end{array}$ & $\begin{array}{l}92 \\
(86.8)\end{array}$ & $16(88.9)$ & $29(87.9)$ & $21(80.8)$ & $54(93.1)$ & $19(79.2)$ & $24(88.9)$ & 439 (81.9) \\
\hline Smoking n (\%) & $\begin{array}{l}125 \\
(14.7)\end{array}$ & $\begin{array}{l}111 \\
(15.0)\end{array}$ & $\begin{array}{l}14 \\
(13.2)\end{array}$ & $2(11.1)$ & $5(15.2)$ & $1(3.8)$ & $10(17.2)$ & $2(8.3)$ & $3(11.1)$ & $86(16.0)$ \\
\hline $\begin{array}{l}\text { Daily snuff } n \\
(\%)\end{array}$ & $\begin{array}{l}113 \\
(13.3)\end{array}$ & $\begin{array}{l}83 \\
(11.2)\end{array}$ & $\begin{array}{l}30 \\
(28.3)\end{array}$ & $2(11.1)$ & $3(9.1)$ & $3(11.5)$ & $8(13.8)$ & $1(4.2)$ & 0 & $76(14.2)$ \\
\hline $\begin{array}{l}\text { Consumption } \\
\text { of alcohol } \\
\text { (Never/ones a } \\
\text { month) n (\%) }\end{array}$ & $\begin{array}{l}491 \\
(57.6)\end{array}$ & $\begin{array}{l}434 \\
(58.5)\end{array}$ & $\begin{array}{l}53 \\
(50.0)\end{array}$ & $9(50.0)$ & $18(54.5)$ & $14(53.8)$ & $32(55.2)$ & $14(58.3)$ & 22 (81.5) & $324(60.4)$ \\
\hline $\begin{array}{l}\text { Daily intake of } \\
\text { vegetables } n \\
\text { (\%) }\end{array}$ & $\begin{array}{l}584 \\
(60.0)\end{array}$ & $\begin{array}{l}471 \\
(63.5)\end{array}$ & $\begin{array}{l}62 \\
(58.5)\end{array}$ & $11(61.1)$ & $23(69.7)$ & $16(61.5)$ & $42(70.7)$ & $22(91.7)$ & $14(51.9)$ & $323(60.3)$ \\
\hline $\begin{array}{l}\text { Physical } \\
\text { exercise n (\%) }\end{array}$ & $\begin{array}{l}423 \\
(47.5)\end{array}$ & $\begin{array}{l}358 \\
(48.2)\end{array}$ & $\begin{array}{l}64 \\
(60.4)\end{array}$ & $7(38.9)$ & $18(54.5)$ & $12(46.2)$ & $35(60.3)$ & $23(95.8)$ & $10(37.0)$ & $262(48.9)$ \\
\hline
\end{tabular}




\begin{tabular}{|c|c|c|c|c|c|c|c|c|c|c|c|}
\hline $\begin{array}{l}\text { physical } \\
\text { activities n (\%) }\end{array}$ & (32.7) & $(34.5)$ & (32.1) & & & & & & & & $(27$. \\
\hline $\begin{array}{l}\text { Sedentary more } \\
\text { than } 10 \mathrm{~h} \mathrm{n}(\%)\end{array}$ & $\begin{array}{l}230 \\
(25.8)\end{array}$ & $\begin{array}{l}196 \\
(26.4)\end{array}$ & $\begin{array}{l}32 \\
(30.2)\end{array}$ & 7 (38.9) & $10(30.3)$ & 9 (34.6) & 18 (31.0) & $5(20.8)$ & $10(37.0)$ & $123(22.9)$ & $\begin{array}{l}48 \\
(37 .:\end{array}$ \\
\hline $\begin{array}{l}\text { Sleeping } \\
\text { problems n (\%) }\end{array}$ & $\begin{array}{l}343 \\
(40.3)\end{array}$ & $\begin{array}{l}300 \\
(40.4)\end{array}$ & $\begin{array}{l}39 \\
(36.8)\end{array}$ & 12 (66.7) & 13 (39.4) & $12(46.2)$ & 19 (32.8) & $11(45.8)$ & 9 (33.3) & $223(41.6)$ & $\begin{array}{l}44 \\
(34 .\end{array}$ \\
\hline
\end{tabular}

Table 2. Reasons for choosing the selected program and career.

\begin{tabular}{|c|c|c|c|c|c|c|c|c|c|c|}
\hline Total & Women & Men & $\begin{array}{l}\text { Biomedical } \\
\text { laboratory } \\
\text { scientist, } \\
\text { (Clin } \\
\text { Phys) } \\
\text { n=18 }\end{array}$ & $\begin{array}{l}\text { Biomedical } \\
\text { laboratory } \\
\text { scientist, } \\
\text { (Lab Med) } \\
\mathrm{n}=33\end{array}$ & $\begin{array}{l}\text { Diagnostic } \\
\text { radiology } \\
\text { nurses }\end{array}$ & $\begin{array}{l}\text { Occupational } \\
\text { therapist }\end{array}$ & $\begin{array}{l}\text { Physio- } \\
\text { therapist }\end{array}$ & $\begin{array}{l}\text { Registered } \\
\text { dental } \\
\text { hygienists }\end{array}$ & $\begin{array}{l}\text { Registered } \\
\text { nurse }\end{array}$ & $\begin{array}{l}\text { Social } \\
\text { worker }\end{array}$ \\
\hline$N=851$ & $n=742$ & $\mathrm{n}=106$ & & & & $\mathrm{n}=58$ & $n=24$ & & $n=536$ & $n=129$ \\
\hline
\end{tabular}

\begin{tabular}{|c|c|c|c|c|c|c|c|c|c|c|c|}
\hline $\begin{array}{l}\text { Teamwork, } \\
\text { n (\%) }\end{array}$ & $\begin{array}{l}527 \\
(61.8)\end{array}$ & $\begin{array}{l}463 \\
(62.4)\end{array}$ & $\begin{array}{l}62 \\
(58.5)\end{array}$ & $8(44.5)$ & 11 (33.3) & $19(73.0)$ & 33 (56.9) & $12(50.0)$ & $10(37.0)$ & $370(69.1)$ & $\begin{array}{l}63 \\
(48.8)\end{array}$ \\
\hline $\begin{array}{l}\text { Employment } \\
\text { security, } \mathrm{n} \\
(\%)\end{array}$ & $\begin{array}{l}791 \\
(92.8)\end{array}$ & $\begin{array}{l}693 \\
(93.4)\end{array}$ & $\begin{array}{l}94 \\
(88.7)\end{array}$ & $18(100)$ & 30 (90.9) & $25(86.2)$ & 53 (91.4) & $23(95.8)$ & $23(85.1)$ & $503(93.8)$ & $\begin{array}{l}115 \\
(89.2)\end{array}$ \\
\hline $\begin{array}{l}\text { Working } \\
\text { with people, } \\
\mathrm{n}(\%)\end{array}$ & $\begin{array}{l}778 \\
(91.4)\end{array}$ & $\begin{array}{l}682 \\
(91.9)\end{array}$ & $\begin{array}{l}93 \\
(87.7)\end{array}$ & $16(88.9)$ & $15(45.5)$ & $22(84.6)$ & $55(94.8)$ & 22 (91.7) & 21 (77.7) & $506(94.4)$ & $\begin{array}{l}120 \\
(93.1)\end{array}$ \\
\hline $\begin{array}{l}\text { Helping } \\
\text { people, } \mathrm{n} \\
(\%)\end{array}$ & $\begin{array}{l}791 \\
(92.8)\end{array}$ & $\begin{array}{l}705 \\
(95.0)\end{array}$ & $\begin{array}{l}99 \\
(93.4)\end{array}$ & $18(100)$ & 30 (90.9) & $25(96.2)$ & $56(96.6)$ & $24(100)$ & $22(81.4)$ & $510(95.1)$ & $\begin{array}{l}122 \\
(94.6)\end{array}$ \\
\hline $\begin{array}{l}\text { The } \\
\text { education is } \\
\text { broad, } \mathrm{n}(\%)\end{array}$ & $\begin{array}{l}750 \\
(88.0)\end{array}$ & $\begin{array}{l}657 \\
(88.5)\end{array}$ & $\begin{array}{l}90 \\
(84.9)\end{array}$ & $17(94.4)$ & $31(94.0)$ & $23(88.5)$ & $54(93.1)$ & $23(95.9)$ & $22(81.5)$ & $482(90.0)$ & $\begin{array}{l}123 \\
(95.3)\end{array}$ \\
\hline $\begin{array}{l}\text { Be able to } \\
\text { choose } \\
\text { different } \\
\text { career } \\
\text { paths, n (\%) }\end{array}$ & $\begin{array}{l}759 \\
(89.1)\end{array}$ & $\begin{array}{l}662 \\
(89.2)\end{array}$ & $\begin{array}{l}93 \\
(87.8)\end{array}$ & 13 (72.2) & 29 (87.9) & $15(57.7)$ & 53 (91.4) & $21(87.5)$ & 16 (59.2) & 490 (91.4) & $\begin{array}{l}121 \\
(93.8)\end{array}$ \\
\hline $\begin{array}{l}\text { Varying } \\
\text { tasks, n (\%) }\end{array}$ & $\begin{array}{l}744 \\
(87.3)\end{array}$ & $\begin{array}{l}653 \\
(88.0)\end{array}$ & $\begin{array}{l}87 \\
(82.1)\end{array}$ & $17(94.4)$ & 30 (90.9) & $24(92.4)$ & $50(86.2)$ & $22(91.7)$ & $18(66.6)$ & $476(88.8)$ & $\begin{array}{l}106 \\
(82.1)\end{array}$ \\
\hline $\begin{array}{l}\text { The work is } \\
\text { intellectual } \\
\text { stimulating, } \\
\mathrm{n}(\%)\end{array}$ & $\begin{array}{l}725 \\
(85.1)\end{array}$ & $\begin{array}{l}639 \\
(86.1)\end{array}$ & $\begin{array}{l}82 \\
(77.4)\end{array}$ & $17(94.4)$ & 30 (90.9) & $24(92.4)$ & $50(86.2)$ & $22(91.7)$ & $18(66.6)$ & $458(85.4)$ & $\begin{array}{l}105 \\
(81.4)\end{array}$ \\
\hline $\begin{array}{l}\text { Get a } \\
\text { permanent } \\
\text { job, n (\%) }\end{array}$ & $\begin{array}{l}741 \\
(87.0)\end{array}$ & $\begin{array}{l}655 \\
(88.2)\end{array}$ & $\begin{array}{l}82 \\
(77.3)\end{array}$ & $16(88.9)$ & $29(87.9)$ & $25(96.1)$ & $52(89.6)$ & $21(87.5)$ & $23(75.2)$ & $465(86.8)$ & $\begin{array}{l}109 \\
(84.5)\end{array}$ \\
\hline $\begin{array}{l}\text { Closeness } \\
\text { to University, } \\
\mathrm{n}(\%)\end{array}$ & $\begin{array}{l}545 \\
(64.0)\end{array}$ & $\begin{array}{l}475 \\
(64.1)\end{array}$ & $\begin{array}{l}68 \\
(64.2)\end{array}$ & 7 (38.9) & $22(63.6)$ & $17(65.4)$ & $38(65.5)$ & $15(62.5)$ & $15(55.5)$ & $348(55.1)$ & $\begin{array}{l}82 \\
(63.6)\end{array}$ \\
\hline $\begin{array}{l}\text { Use the } \\
\text { knowledge } \\
\text { from my } \\
\text { education, n }\end{array}$ & $\begin{array}{l}778 \\
(91.3)\end{array}$ & $\begin{array}{l}680 \\
(91.6)\end{array}$ & $\begin{array}{l}95 \\
(89.6)\end{array}$ & $18(100)$ & $30(90.9)$ & $26(100)$ & 52 (89.7) & $24(100)$ & $23(85.1)$ & $490(91.5)$ & $\begin{array}{l}114 \\
(88.3)\end{array}$ \\
\hline
\end{tabular}

(\%)

Tabel 3. Health-promoting resources measured using SOC and subscales, SHIS and OBQ 


\begin{tabular}{|c|c|c|c|c|c|c|c|c|c|c|c|}
\hline & Total & Women & Men & $\begin{array}{l}P \\
\text { value }\end{array}$ & $\begin{array}{l}\text { Biomedical } \\
\text { laboratory } \\
\text { scientist, } \\
\text { (clin phys) }\end{array}$ & $\begin{array}{l}\text { Biomedical } \\
\text { laboratory } \\
\text { scientist, } \\
\text { (lab med) }\end{array}$ & $\begin{array}{l}\text { Diagnostic } \\
\text { radiology } \\
\text { nurses }\end{array}$ & $\begin{array}{l}\text { Occupational } \\
\text { Therapist }\end{array}$ & $\begin{array}{l}\text { Physio- } \\
\text { therapist }\end{array}$ & $\begin{array}{l}\text { Registered } \\
\text { dental } \\
\text { hygienists }\end{array}$ & $\begin{array}{l}\text { Regist } \\
\text { nurse }\end{array}$ \\
\hline & $N=851$ & $n=742$ & $n=106$ & & $n=18$ & $n=33$ & $n=26$ & $n=58$ & $n=24$ & $n=27$ & $n=536$ \\
\hline $\begin{array}{l}\text { SOC Total } \\
13-91 \text { (sd) }\end{array}$ & $\begin{array}{l}59.09 \\
(11.78)\end{array}$ & $\begin{array}{l}58.87 \\
(11.84)\end{array}$ & $\begin{array}{l}61.11 \\
(10.86)\end{array}$ & .083 & $\begin{array}{l}57.39 \\
(10.94)\end{array}$ & $\begin{array}{l}56.45 \\
(13.23)\end{array}$ & $\begin{array}{l}59.73 \\
(12.98)\end{array}$ & $\begin{array}{l}60.82 \\
(11.00)\end{array}$ & $\begin{array}{l}57.00 \\
(12.63)\end{array}$ & $\begin{array}{l}56.73 \\
(11.53)\end{array}$ & $\begin{array}{l}59.40 \\
(11.78\end{array}$ \\
\hline $\begin{array}{l}\text { Comprehensibility } \\
1-35 \text { (sd) }\end{array}$ & $\begin{array}{l}20.69 \\
(5.39)\end{array}$ & $\begin{array}{l}20.52 \\
(5.45)\end{array}$ & $\begin{array}{l}21.99 \\
(4.75)\end{array}$ & .011 & $\begin{array}{l}21.06 \\
(4.95)\end{array}$ & $\begin{array}{l}18.76 \\
(6.09)\end{array}$ & $\begin{array}{l}21.12 \\
(5.75)\end{array}$ & $21.20(5.47)$ & $\begin{array}{l}19.54 \\
(5.32)\end{array}$ & $\begin{array}{l}19.08 \\
(5.83)\end{array}$ & $\begin{array}{l}20.93 \\
(5.38)\end{array}$ \\
\hline $\begin{array}{l}\text { Meaningfulness } \\
1-28 \text { (sd) }\end{array}$ & $\begin{array}{l}20.62 \\
(4.10)\end{array}$ & $\begin{array}{l}20.76 \\
(4.01)\end{array}$ & $\begin{array}{l}19.83 \\
(4.49)\end{array}$ & .030 & $\begin{array}{l}19.39 \\
(4.70)\end{array}$ & $\begin{array}{l}19.79 \\
(4.33)\end{array}$ & $\begin{array}{l}20.62 \\
(4.72)\end{array}$ & 21.39 (3.47) & $\begin{array}{l}20.00 \\
(4.10)\end{array}$ & $\begin{array}{l}19.92 \\
(3.38)\end{array}$ & $\begin{array}{l}20.67 \\
(4.11)\end{array}$ \\
\hline $\begin{array}{l}\text { Manageability } \\
1-28 \text { (sd) }\end{array}$ & $\begin{array}{l}17.82 \\
(4.37)\end{array}$ & $\begin{array}{l}17.66 \\
(4.38)\end{array}$ & $\begin{array}{l}19.07 \\
(4.13)\end{array}$ & .002 & $\begin{array}{l}16.94 \\
(2.88)\end{array}$ & $\begin{array}{l}17.91 \\
(4.67)\end{array}$ & $\begin{array}{l}18.00 \\
(4.00)\end{array}$ & $18.23(4.07)$ & $\begin{array}{l}17.46 \\
(4.62)\end{array}$ & $\begin{array}{l}17.73 \\
(4.38)\end{array}$ & $\begin{array}{l}17.79 \\
(4.35)\end{array}$ \\
\hline $\begin{array}{l}\text { SHIS } \\
12-72 \text { (sd) }\end{array}$ & $\begin{array}{l}44.04 \\
(9.38)\end{array}$ & $\begin{array}{l}43.83 \\
(9.37)\end{array}$ & $\begin{array}{l}45.86 \\
(9.10)\end{array}$ & .032 & $\begin{array}{l}42.83 \\
(8.56)\end{array}$ & $\begin{array}{l}46.09 \\
(8.19)\end{array}$ & $\begin{array}{l}43.65 \\
(9.25)\end{array}$ & 47.40 (8.07) & $\begin{array}{l}42.33 \\
(8.99)\end{array}$ & $\begin{array}{l}39.81 \\
(9.98)\end{array}$ & $\begin{array}{l}43.71 \\
(9.77)\end{array}$ \\
\hline $\begin{array}{l}\text { OBQ } \\
11-44 \text { (sd) }\end{array}$ & $\begin{array}{l}26,40 \\
(7.07)\end{array}$ & $\begin{array}{l}26.28 \\
(7.11)\end{array}$ & $\begin{array}{l}27.28 \\
(6.80)\end{array}$ & .137 & $\begin{array}{l}29.38 \\
(6.42)\end{array}$ & $\begin{array}{l}27.77 \\
(6.21)\end{array}$ & $\begin{array}{l}26.80 \\
(6.27)\end{array}$ & $26.91(7.35)$ & $\begin{array}{l}26.57 \\
(6.78)\end{array}$ & $\begin{array}{l}24.68 \\
(6.78)\end{array}$ & $\begin{array}{l}26.12 \\
(7.27)\end{array}$ \\
\hline
\end{tabular}

Table 4 Differences in general health, perceived wellbeing and health-promoting lifestyle factors on general health, SOC, SHIS, and OBQ respectively 


\begin{tabular}{|c|c|c|c|}
\hline General health ${ }^{b}$ & Yes, n (\%) & No, $n(\%)$ & $p$-value \\
\hline Sex (Woman) & $660(89.6)$ & $104(86.6)$ & 0.354 \\
\hline Perceived wellbeing (Good) & $672(94.5)$ & $77(58.3)$ & $<0.001$ \\
\hline High-intensity exercise (Physical exercises) > 60-90 min/week & $398(53.1)$ & $23(24.5)$ & $<0.001$ \\
\hline Moderate-intensity physical activity (Everyday physical activities) $>150 \mathrm{~min} /$ week & $260(34.7)$ & $29(30.9)$ & 0.462 \\
\hline Sedentary $>10$ h/day & $193(85.0)$ & $558(90.3)$ & 0.031 \\
\hline Sleeping problems & $279(82.1)$ & $468(93.4)$ & $<0.001$ \\
\hline Daily intake of vegetables & $487(64.8)$ & $45(47.9)$ & $<0.001$ \\
\hline Consumption of alcohol & $421(86.4)$ & $330(92.2)$ & 0.009 \\
\hline Smoking & $102(81.6)$ & $648(90.1)$ & 0.005 \\
\hline Daily snuff & $96(85.0)$ & $649(89.4)$ & 0.164 \\
\hline $\operatorname{soc}^{a}$ & Yes, Mean (sd) & No, Mean (sd) & $p$-value \\
\hline Sex (Woman) & $58.87(11.84)$ & $61.11(10.86)$ & 0.071 \\
\hline General health (Good) & $60.20(11.44)$ & $50.61(11.13)$ & $<0.001$ \\
\hline Perceived wellbeing (Good) & $61.31(10.83)$ & $47.02(9.12)$ & $<0.001$ \\
\hline High-intensity exercise (Physical exercises) $>60-90 \mathrm{~min} /$ week & $59.89(11.99)$ & $58.31(11.53)$ & 0.053 \\
\hline Moderate-intensity physical activity (Everyday physical activities) > $150 \mathrm{~min} /$ week & $60.87(11.99)$ & $58.18(11.58)$ & 0.002 \\
\hline Sedentary $>10 \mathrm{~h} /$ day & $56.53(11.37)$ & $60.04(11.79)$ & $<0.001$ \\
\hline Sleeping problems & $54.21(11.19)$ & $62.34(11.03)$ & $<0.001$ \\
\hline Daily intake of vegetables & $60.30(11.90)$ & $57.05(11.29)$ & $<0.001$ \\
\hline Consumption of alcohol & $58.34(11.53)$ & $60.11(12.04)$ & 0.032 \\
\hline Smoking & $56.30(11.82)$ & $59.63(11.70)$ & 0.004 \\
\hline Daily snuff & $58.21(11.10)$ & $59.16(11.87)$ & 0.429 \\
\hline$S H I S^{a}$ & Yes, Mean (sd) & No, Mean (sd) & $p$-value \\
\hline Sex (Woman) & $43.83(9.37)$ & $45.86(9.10)$ & 0.037 \\
\hline General health (Good) & $44.95(8.91)$ & $36.54(9.73)$ & $<0.001$ \\
\hline Perceived wellbeing (Good) & $45.71(8.56)$ & $34.91(8.35)$ & $<0.001$ \\
\hline High-intensity exercise (Physical exercises) $>60-90 \mathrm{~min} /$ week & $44.99(9.13)$ & $43.09(9.51)$ & 0.003 \\
\hline Moderate-intensity physical activity (Everyday physical activities) > $150 \mathrm{~min} /$ week & $44.82(9.20)$ & $43.63(9.44)$ & 0.078 \\
\hline Sedentary $>10 \mathrm{~h} /$ day & $42.16(10.13)$ & $44.73(9.00)$ & $<0.001$ \\
\hline Sleeping problems & $39.81(8.84)$ & $46.88(8.67)$ & $<0.001$ \\
\hline Daily intake of vegetables & $44.37(9.44)$ & $43.44(9.25)$ & 0.003 \\
\hline Consumption of alcohol & $42.99(9.35)$ & $45.47(9.25)$ & $<0.001$ \\
\hline Smoking & $42.64(9.82)$ & $44.26(9.29)$ & 0.075 \\
\hline Daily snuff & $43.54(8.79)$ & $44.07(9.48)$ & 0.577 \\
\hline$O B Q^{C}$ & Yes, Mean (sd) & No, Mean (sd) & $p$-value \\
\hline Sex (Woman) & $26.28(7.11)$ & $27.28(6.80)$ & 0.137 \\
\hline General health (Good) & $26.84(7.02)$ & $22.73(6.40)$ & $<0.001$ \\
\hline Perceived wellbeing (Good) & $27.24(6.82)$ & $21.87(6.66)$ & $<0.001$ \\
\hline High-intensity exercise (Physical exercises) > 60-90 min/week & $27.19(7.18)$ & $26.11(6.85)$ & $<0.001$ \\
\hline
\end{tabular}




\begin{tabular}{lllc} 
Moderate-intensity physical activity (Everyday physical activities) $>150$ min/week & $26.42(7.12)$ & $26.39(7.01)$ & 0.697 \\
\hline Sedentary $>10 \mathrm{~h} /$ day & $26.60(7.25)$ & $26.32(7.01)$ & 0.842 \\
\hline Sleeping problems & $24.74(6.78)$ & $27.50(7.05)$ & $<0.001$ \\
\hline Daily intake of vegetables & $26.54(7.18)$ & $26.11(6.85)$ & 0.357 \\
\hline Consumption of alcohol & $25.75(6.97)$ & $27.29(7.12)$ & 0.002 \\
\hline Smoking & $26.09(6.82)$ & $26.43(7.11)$ & 0.525 \\
\hline Daily snuff & $25.42(7.01)$ & $26.51(7.01)$ & 0.206
\end{tabular}

${ }^{\text {a }}$ T-test, ${ }^{b}$ Chi-square, ${ }^{c}$ Mann-Whitney

Table 5 Multiple Logistic Regression of the Predictive Factors of General Health

\begin{tabular}{lllll} 
& \multicolumn{2}{l}{ Dependant variable General Health } \\
& B (SE) & Odds ratio & $95 \% \mathrm{Cl}$ & $p$-value \\
Variables & & & & \\
\hline Perceived wellbeing & $2.239(0.261)$ & 0.107 & $0.64-0.18$ & $<0.001$ \\
\hline High-intensity exercise (Physical exercises) $>60-90 \mathrm{~min} /$ week & $1.138(0.278)$ & 0.320 & $0.19-0.55$ & $<0.001$ \\
\hline Sedentary $>10 \mathrm{~h} /$ day & $-0.115(0.278)$ & 1.122 & $0.66-1.90$ & 0.668 \\
\hline Sleeping problems & $-0.526(0.263)$ & 1.693 & $1.01-2.83$ & 0.045 \\
\hline Daily intake of vegetables & $0.402(0.252)$ & 0.669 & $0.41-1.10$ & 0.111 \\
\hline Consumption of alcohol & $-0.478(0.279)$ & 0.620 & $0.36-1.07$ & 0.087 \\
\hline Smoking & $-0.736(0.315)$ & 2.087 & $1.13-3.87$ & 0.020
\end{tabular}

Note. $\mathrm{Cl}=$ confidence interval; $\mathrm{R}^{2}=0.158($ Cox \& Snell); $\sigma 0.313$ (Nagelkerke), Model $\chi 2=143.873, \mathrm{p}=<0.001$

Table 6 Multiple Linear Regression Analysis of the Predictive Factors of SOC

\begin{tabular}{|c|c|c|c|c|}
\hline & \multicolumn{4}{|c|}{ Dependant variable SOC } \\
\hline & $\beta$ & Standard & $95 \% \mathrm{Cl}$ & $p$-value \\
\hline Variables & & errror $(\beta)$ & & \\
\hline General health & 1.993 & 1.237 & $-4.42-0.44$ & 0.101 \\
\hline Perceived wellbeing & 11.118 & 1.093 & $-13.26--8.97$ & $<0.001$ \\
\hline Moderate-intensity physical activity (Everyday physical activities) $>150 \mathrm{~min} /$ week & 2.033 & 0.757 & $-3.52-0.55$ & 0.007 \\
\hline Sedentary $>10 \mathrm{~h} /$ day & -1.760 & 0.811 & $0.17-3.35$ & 0.030 \\
\hline Sleeping problems & -5.565 & 0.751 & $4.09-7.04$ & $<0.001$ \\
\hline Daily intake of vegetables & 1.217 & 0.749 & $-2.69-0.25$ & 0.105 \\
\hline Consumption of alcohol & -0.407 & 0.733 & $-1.85-1.03$ & 0.579 \\
\hline Smoking & -2.122 & 0.999 & $0.16-4.08$ & 0.034 \\
\hline
\end{tabular}

Note. $\mathrm{Cl}=$ confidence interval; $\mathrm{R}^{2}=0.275 ;$ ANOVA: $\mathrm{F}=38.25, \mathrm{p}=<.001$. 


\section{Dependant variable SHIS}

\begin{tabular}{|c|c|c|c|c|}
\hline Variables & $\beta$ & $\begin{array}{l}\text { Standard } \\
\text { errror }(\beta)\end{array}$ & $95 \% \mathrm{Cl}$ & $p$-value \\
\hline Sex & -1.444 & $0.853-$ & $-3.12-0.23$ & 0.091 \\
\hline General health & 2.830 & 0.994 & $-4.78--0.88$ & 0.005 \\
\hline Perceived wellbeing & 7.737 & 0.861 & $-9.43--6.05$ & $<0.001$ \\
\hline High-intensity exercise (Physical exercises) $>60-90 \mathrm{~min} /$ week & 0.486 & 0.588 & $-1.64-0.67$ & 0.669 \\
\hline Moderate-intensity physical activity (Everyday physical activities) $>150 \mathrm{~min} /$ week & 0.880 & 0.607 & $-2.07-0.31$ & 0.147 \\
\hline Sedentary $>10 \mathrm{~h} /$ day & -1.250 & 0.642 & $-0.01-2.51$ & 0.052 \\
\hline Sleeping problems & -5.160 & 0.589 & $4.00-6.32$ & $<0.001$ \\
\hline Daily intake of vegetables & 0.285 & 0.590 & $-0.87-1.45$ & 0.629 \\
\hline Consumption of alcohol & -1.163 & 0.572 & $-2.29--0.05$ & 0.042 \\
\hline
\end{tabular}

Note. $\mathrm{Cl}=$ confidence interval; $: \mathrm{R}^{2}=0.273$; ANOVA: $\mathrm{F}=34.38, \mathrm{p}=<.001$.

Table 8 Multiple Linear Regression Analysis of the Predictive Factors of OBQ

\begin{tabular}{lllll} 
& \multicolumn{4}{l}{ Dependant variable OBQ } \\
& $\beta$ & Standard & $95 \% \mathrm{Cl}$ & $p$-value \\
Variables & $\beta$ & errror $(\beta)$ & & \\
\hline General health & 1.173 & 0.859 & $-2.86-0.51$ & 0.173 \\
\hline Perceived wellbeing & 4.150 & 0.738 & $-5.60--2.70$ & $<0.001$ \\
\hline High-intensity exercise (Physical exercises) $>60-90$ min/week & 1.026 & 0.487 & $-1.98--0.07$ & 0.036 \\
\hline Sleeping problems & -1.715 & 0.506 & $0.72-2.71$ & 0.001 \\
\hline Consumption of alcohol & -0.749 & 0.492 & $-1.71-0.22$ & 0.217
\end{tabular}

Note. $\mathrm{Cl}=$ confidence interval; $\mathrm{R}^{2}=0.106 ;$ ANOVA: $\mathrm{F}=18.51, \mathrm{p}=<.001$. 